Article

\title{
Mn-doped $\mathrm{CeO}_{2}$ Nanorod Supported Au Catalysts for Dehydrogenation of Ethane with $\mathrm{CO}_{2}$
}

\author{
Tianqi Lei ${ }^{1}$, Hongyao Guo ${ }^{1}$, Changxi Miao ${ }^{2}$, Weiming Hua ${ }^{1}$, Yinghong Yue ${ }^{1, *}$ and Zi Gao ${ }^{1}$ \\ 1 Department of Chemistry, Shanghai Key Laboratory of Molecular Catalysis and Innovative Materials, \\ Fudan University, Shanghai 200438, China; leitianqi90@126.com (T.L.); guohongyao@163.com (H.G.); \\ wmhua@fudan.edu.cn (W.H.); zigao@fudan.edu.cn (Z.G.) \\ 2 Shanghai Research Institute of Petrochemical Technology, Shanghai 201208, China; \\ miaocx.sshy@sinopec.com \\ * Correspondence: yhyue@fudan.edu.cn; Tel.: +86-21-31249120
}

Received: 15 January 2019; Accepted: 27 January 2019; Published: 30 January 2019

\begin{abstract}
Dehydrogenation of ethane to ethylene was investigated in the presence of $\mathrm{CO}_{2}$ over $\mathrm{Au}$ catalyst supported on an Mn-doped ceria nanorod. The activity can be greatly enhanced by proper Mn doping. Mn was found to preferentially occupy defect sites or surface sites of ceria, resulting in the formation of extra oxide ions. Characterization results indicated that the reducible oxygen species related to ceria might play a vital role in the dehydrogenation. The addition of $\mathrm{CO}_{2}$ improved the stability of the catalysts remarkably, since $\mathrm{CO}_{2}$ can sustainably replenish the reducible oxygen species and eliminate the coke on the surface of the catalysts, which was proved by the $\mathrm{H}_{2}$-TPR and Raman analysis of spent catalysts. An ethane conversion of $17.4 \%$ with an ethylene selectivity of $97.5 \%$ can be obtained after $44 \mathrm{~h}$ of reaction.
\end{abstract}

Keywords: Ethane dehydrogenation; Au catalyst; Mn-doping; $\mathrm{CeO}_{2}$ nanorod; $\mathrm{CO}_{2}$

\section{Introduction}

Being one of the most important types of compounds in the chemical industry, ethylene can be extensively used as feedstock for producing polyethylene, ethylene oxide, ethylene glycol, vinyl chloride, acetaldehyde, acetic acid and other derivates. The catalytic dehydrogenation of ethane to ethylene has drawn intense attention due to the increasing demand for replacing the utilization of petroleum with nature gas and shale gas [1,2]. Compared with direct alkane dehydrogenation, oxidative dehydrogenation with $\mathrm{CO}_{2}$ is more advantageous because higher equilibrium conversion and lower carbon deposits can be achieved via reverse water-gas shift reaction (RWGS) and Boudouard reaction [3-6].

The dehydrogenation of light paraffins in the presence of $\mathrm{CO}_{2}$ has been widely researched in the previous decade. $\mathrm{Cr}_{2} \mathrm{O}_{3}$ - and $\mathrm{Ga}_{2} \mathrm{O}_{3}$-based catalysts are reported to be more active than others for the reaction [7-11]. Nevertheless, these kinds of catalysts are still limited by the drawbacks of environmental hostility, relatively low selectivity or poor long-term stability. Recently, the reaction between ethane/propane and $\mathrm{CO}_{2}$ has been studied on Au-based catalysts [12,13]. Dry reforming as well as oxidative dehydrogenation can occur over these supported Au catalysts. More recent results show that $\mathrm{CeO}_{2}$-supported $\mathrm{Au}$ is an excellent catalyst for oxidative dehydrogenation of ethane with $\mathrm{CO}_{2}$, and nanorod $\mathrm{CeO}_{2}$-supported Au exhibits higher activity and better stability than nanoparticle supported one [14]. The surface oxygen reducibility of ceria is found to play a vital role in dehydrogenation.

$\mathrm{CeO}_{2}$ has been commonly employed as a catalyst or catalyst support for various redox reactions due to its high oxygen storage/release capacities [15-18]. Significant enhancement has been reported 
in redox properties as well as catalytic activities by the doping of other transition metal oxides [19, 20], among which manganese oxide $\left(\mathrm{MnO}_{\mathrm{x}}\right)$ has been proved to be an excellent doping agent for $\mathrm{CeO}_{2}$-based catalysts for many redox reactions such as ammonia oxidation, volatile organic compound combustion and $\mathrm{CO}$ oxidation [21-23].

In this contribution, $\mathrm{Mn}$-doped $\mathrm{CeO}_{2}$ nanorod was synthesized and utilized as a support for an $\mathrm{Au}$ catalyst. The catalyst was characterized by XRD, TEM, XPS, $\mathrm{H}_{2}-\mathrm{TPR}$, Raman and $\mathrm{N}_{2}$ adsorption, and the catalytic performance for the dehydrogenation of ethane to ethylene in the presence of $\mathrm{CO}_{2}$ was established. The effects of $\mathrm{Mn}$ doping and $\mathrm{CO}_{2}$ addition on the dehydrogenation reaction are also discussed herein on the basis of characterization.

\section{Results and Discussion}

\subsection{Catalyst Characterization}

The XRD patterns of $\mathrm{Ce}_{1-x} \mathrm{Mn}_{x} \mathrm{O}_{2-\delta}$-supported Au catalysts with various $\mathrm{Mn} / \mathrm{Ce}$ ratios are illustrated in Figure 1. All the catalysts exhibited only $\mathrm{CeO}_{2}$ cubic fluorite diffraction peaks $\left(2 \theta=28.6^{\circ}\right.$, $33.1^{\circ}, 47.5^{\circ}$ and $56.5^{\circ}$, PDF\# 81-0792) without any peaks of manganese oxide phases. A progressive shift to high Bragg angle and width-broadening of the diffraction peaks can also be observed, indicating that the manganese species entered in the $\mathrm{CeO}_{2}$ lattice and formed $\mathrm{Ce}_{1-x} \mathrm{Mn}_{x} \mathrm{O}_{2-\delta}$ solid solution [24]. The pure manganese oxide exhibited dominant diffraction peaks at $2 \theta=32.9^{\circ}$ and $38.2^{\circ}$, which are the characteristics of $\mathrm{Mn}_{2} \mathrm{O}_{3}$ (PDF\#89-4836 /65-1798). No distinct diffraction peak attributed to the $\mathrm{Au}$ phase was observed, revealing the high dispersion of the gold species on these supports.

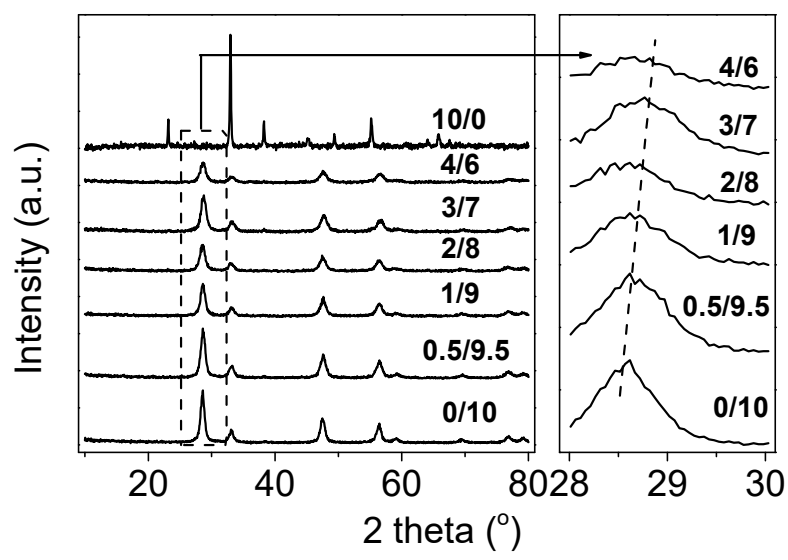

Figure 1. XRD patterns of $\mathrm{Ce}_{1-x} \mathrm{Mn}_{x} \mathrm{O}_{2-\delta}$-supported Au catalysts with different Mn/Ce ratios.

The morphologies of the $\mathrm{CeO}_{2}$ and $\mathrm{Mn}$-doped $\mathrm{CeO}_{2}$ materials after $\mathrm{Au}$ loading were attained by TEM and the images are shown in Figure 2. $\mathrm{Au} / \mathrm{CeO}_{2}$ displayed the morphology of the nanorod, whose diameter is $11.5 \pm 1.0 \mathrm{~nm}$ and length is in the range of 42 to $65 \mathrm{~nm}$, exactly the same as the results reported before [14]. Previous studies have shown that this $\mathrm{CeO}_{2}$ nanorod grows along the [110] direction, exposing mostly less stable $\{001\}$ and $\{110\}$ crystal planes which gives rise to higher redox activity and better dispersion of Au nanoclusters [25,26]. The doping of $\mathrm{Mn}$ did not alter the nanorod morphology of the $\mathrm{CeO}_{2}$ but led to progressive shortening of the length, in accordance with the widening of the $\mathrm{X}$-ray diffraction peaks. Taking the $\mathrm{Au} / \mathrm{Ce}_{0.6} \mathrm{Mn}_{0.4}$ catalyst for example, the length of the nanorod was decreased to $19 \sim 32 \mathrm{~nm}$. By contrast, the $\mathrm{Au} / \mathrm{Mn}_{2} \mathrm{O}_{3}$ catalyst showed no unique morphology, just block mass with much bigger sizes. 

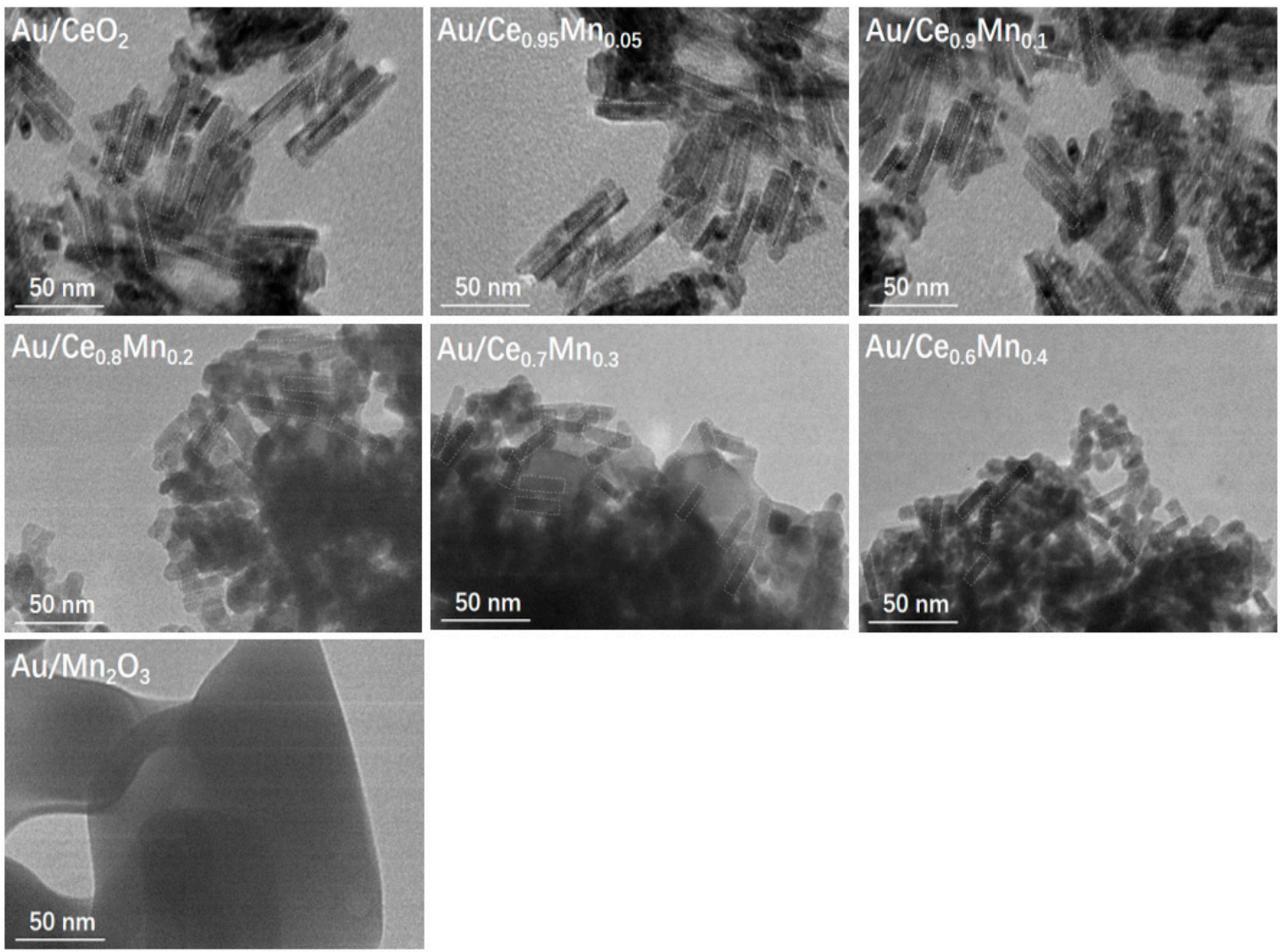

Figure 2. TEM images of the $\mathrm{Au} / \mathrm{Ce}_{1-x} \mathrm{Mn}_{x} \mathrm{O}_{2-\delta}$ catalysts with different $\mathrm{Mn} / \mathrm{Ce}$ ratios.

Textural properties of the catalysts are obtained via $\mathrm{N}_{2}$ adsorption, and the results are shown in Table 1 . The specific surface areas of the $\mathrm{CeO}_{2}$-based catalysts changed little after the Mn-doping. However, they are much higher than that of the $\mathrm{Au} / \mathrm{Mn}_{2} \mathrm{O}_{3}$ catalyst.

Table 1. Textural and structural properties of the $\mathrm{Au} / \mathrm{Ce}_{1-x} \mathrm{Mn}_{x} \mathrm{O}_{2-\delta}$ samples.

\begin{tabular}{ccccc}
\hline Catalysts & $\mathbf{S}_{\text {BET }}\left(\mathbf{m}^{\mathbf{2}} \mathbf{g}\right)$ & $\mathbf{C e}^{3+}$ Percent & Surface Ce/Mn Ratio & $\mathbf{M n}^{2+}$ in Total Mn (\%) \\
\hline $\mathrm{Au} / \mathrm{CeO}_{2}$ & 66 & 28.0 & - & - \\
$\mathrm{Au} / \mathrm{Ce}_{0.95} \mathrm{Mn}_{0.05}$ & 65 & 16.7 & 15.8 & - \\
$\mathrm{Au} / \mathrm{Ce}_{0.9} \mathrm{Mn}_{0.1}$ & 67 & 16.5 & 9.8 & - \\
$\mathrm{Au} / \mathrm{Ce}_{0.8} \mathrm{Mn}_{0.2}$ & 62 & 7.9 & 4.6 & 8.0 \\
$\mathrm{Au} / \mathrm{Ce}_{0.7} \mathrm{Mn}_{0.3}$ & 59 & 6.6 & 3.3 & 5.3 \\
$\mathrm{Au} / \mathrm{Ce}_{0.6} \mathrm{Mn}_{0.4}$ & 62 & 6.3 & 1.9 & 3.4 \\
$\mathrm{Au} / \mathrm{Mn}_{2} \mathrm{O}_{3}$ & 3 & - & - & 1.8 \\
\hline
\end{tabular}

The Raman spectra of $\mathrm{Au} / \mathrm{Ce}_{1-x} \mathrm{Mn}_{x} \mathrm{O}_{2-\delta}$ catalysts are illustrated in Figure 3. The $\mathrm{Au} / \mathrm{CeO}_{2}$ mainly exhibited a peak at $459 \mathrm{~cm}^{-1}$ due to the ceria $\mathrm{F}_{2 \mathrm{~g}}$ active mode. Such a characteristic peak shifted to a lower wavenumber at around $442 \mathrm{~cm}^{-1}$ after the Mn doping, which was caused by the incorporation of $\mathrm{Mn}$ ions in the $\mathrm{CeO}_{2}$ matrix $[27,28]$. The manganese oxides exhibited a relatively weak Raman peak at around $634 \mathrm{~cm}^{-1}$ which can only be observed in the $\mathrm{Ce}_{1-x} \mathrm{Mn}_{x} \mathrm{O}_{2-\delta}$ samples with high Mn molar ratio $(x>0.3)[27,29]$. The $\mathrm{Au} / \mathrm{CeO}_{2}$ also exhibited a weak peak at $\sim 268 \mathrm{~cm}^{-1}$ and $\sim 600 \mathrm{~cm}^{-1}$, which is attributed to the oxygen vacancies caused by the presence of $\mathrm{Ce}^{3+}$. However, this peak did not appear in all of the Mn-doping samples, indicating the consumption of oxygen vacancies. It was reported that the $\mathrm{Mn}^{3+}$, whose ionic radius $(58 \mathrm{pm})$ is much smaller than that of host $\mathrm{Ce}^{4+}$ (114 pm), seemed to preferentially occupy the surface or defect sites of $\mathrm{CeO}_{2}$ crystals, causing the disappearance of $\mathrm{O}^{2-}$ vacancies and/or the creation of extra oxide ions [27]. 


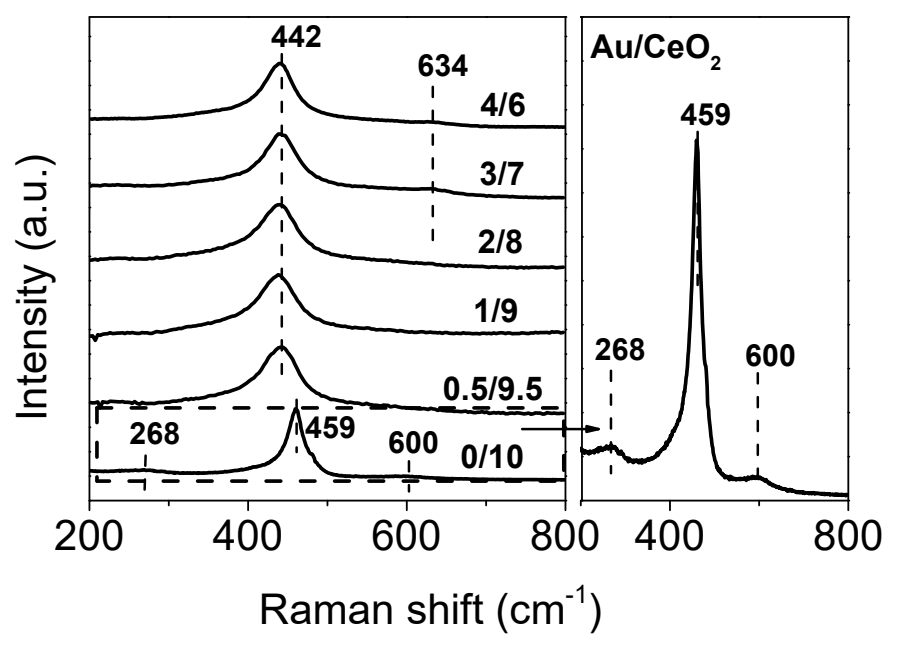

Figure 3. Raman spectra of the $\mathrm{Au} / \mathrm{Ce}_{1-x} \mathrm{Mn}_{x} \mathrm{O}_{2-\delta}$ catalysts with different $\mathrm{Mn} / \mathrm{Ce}$ ratios.

XPS spectra were established to examine the surface composition and chemical states of $\mathrm{Ce}, \mathrm{Mn}$ and $\mathrm{Au}$, and the results are shown in Figure S1 and Table 1. The surface Ce/Mn ratio is a bit lower than the stoichiometry with low Mn content $(x \leq 0.1)$ and becomes higher with increasing Mn content $(x>0.1)$, indicating that the manganese species tended to disperse on the surface firstly and later enriched in the bulk phase. The complex spectra of Ce $3 \mathrm{~d}$ were numerically fitted with 10 peaks. The six bands labeled as $\mathrm{v}_{0}, \mathrm{v}_{1}, \mathrm{v}_{2}, \mathrm{v}_{0}{ }^{\prime}, \mathrm{v}_{1}{ }^{\prime}$, and $\mathrm{v}_{2}{ }^{\prime}$ are characteristic of $\mathrm{Ce}^{4+}$ while the rest labeled as $\mathrm{u}_{0}, \mathrm{u}_{1}, \mathrm{u}_{0}{ }^{\prime}$, and $\mathrm{u}_{1}{ }^{\prime}$ are representative of the $\mathrm{Ce} 3 \mathrm{~d}_{5 / 2}$ component of $\mathrm{Ce}^{3+}$ [30]. The relative contents of $\mathrm{Ce}^{3+}$ were derived from the calculation of the ratio of peak area, which clearly showed that the $\mathrm{Ce}^{3+}$ concentration decreased monotonously with the increasing content of $\mathrm{Mn}$, suggesting that the doping of Mn might occupy the defect sites of ceria and thus, increase the oxidation states of surface $\mathrm{Ce}$. This is consistent with the Raman results. The above results are also proved by Mn $2 p$ XPS spectra of the samples which show predominately $\mathrm{Mn} 2 \mathrm{p}_{3 / 2}$ and $\mathrm{Mn} 2 \mathrm{p}_{1 / 2}$ peaks at around 641.1 and $652.9 \mathrm{eV}$ corresponding to the $\mathrm{Mn}^{3+}$. A small fraction of $\mathrm{Mn}^{2+}$ also existed with binding energy at 640.0 and $651.2 \mathrm{eV}[20,27]$. An increased fraction of $\mathrm{Mn}^{2+}$ was exited in the Ce-Mn composite oxides, indicating the electrons are transferred from Ce to Mn for charge compensation since the doping of $\mathrm{Mn}$ increased the surface $\mathrm{Ce}^{4+}$ species in ceria. The Au $4 \mathrm{f}$ XPS spectra of the samples are also exhibited in Figure S1. $\mathrm{Au} / \mathrm{Mn}_{2} \mathrm{O}_{3}$ consists of a pair of distinct peaks at around 83.7 and $87.4 \mathrm{eV}$ assigned to metallic $\mathrm{Au}$ and additional shoulders at 85.1 and $89.0 \mathrm{eV}$ representing the oxidized surface $\mathrm{Au}^{\delta+}$ species with much smaller fraction [31]. All the Ce-containing samples exhibit similar Au 4f peaks. However, their intensities were much lower than that of the $\mathrm{Au} / \mathrm{Mn}_{2} \mathrm{O}_{3}$ and cannot be deconvoluted effectively.

\subsection{TPR Studies}

The redox behavior of $\mathrm{Ce}_{1-x} \mathrm{Mn}_{x} \mathrm{O}_{2-\delta}$-supported Au materials was determined and the results are presented in Figure 4. Pure ceria often showed two reduction peaks, attributed to reducible surface oxygen and bulk oxygen species, respectively [14]. For the pure manganese oxide, the profiles were featured by two reduction peaks attributed to the reduction of $\mathrm{Mn}_{2} \mathrm{O}_{3}$ to $\mathrm{Mn}_{3} \mathrm{O}_{4}$ and further reduction of $\mathrm{Mn}_{3} \mathrm{O}_{4}$ to $\mathrm{MnO}$ according to previous research [32]. Since the reduction peak of those easily reducible ceria species overlapped with the low-temperature reduction peak of the manganese species in the TPR profiles of $\mathrm{Au} / \mathrm{Ce}_{1-x} \mathrm{Mn}_{x} \mathrm{O}_{2-\delta}$, deconvolution was established and is exhibited in Figure S2. The detailed $\mathrm{H}_{2}$ consumption amount is presented in Table 2. The total $\mathrm{H}_{2}$ consumption amount of the $\mathrm{Au} / \mathrm{Ce}_{1-x} \mathrm{Mn}_{x} \mathrm{O}_{2-\delta}$ was increased proportionally with the increasing Mn doping amount. However, the consumed hydrogen attributed to the ceria species was increased initially, and then decreased with the $\mathrm{Mn}$ amount, reaching the maximum value of $0.33 \mathrm{mmol} / \mathrm{g}$ over $\mathrm{Au} / \mathrm{Ce}_{0.9} \mathrm{Mn}_{0.1}$. This is obviously an integrated result because on the one hand the doping of Mn decreased the ceria molar percent in 
the composite oxides, while on the other hand, it occupied the defect or surface sites and generated extra oxide ions related to the Ce ions as revealed by the Raman and XPS measurement.

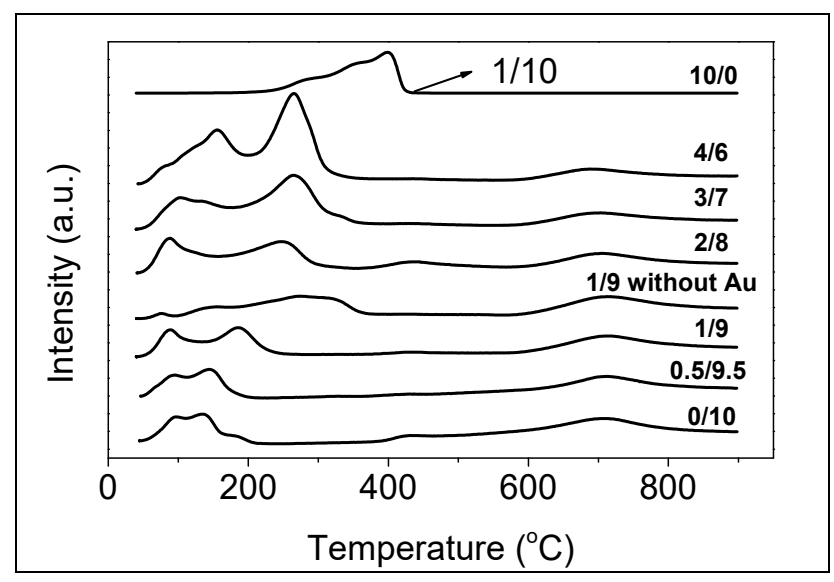

Figure 4. TPR profiles of $\mathrm{Ce}_{1-x} \mathrm{Mn}_{x} \mathrm{O}_{2-\delta}$-supported Au catalysts with different $\mathrm{Mn} / \mathrm{Ce}$ ratios.

Table 2. $\mathrm{H}_{2}$-TPR results of the Au-supported catalysts.

\begin{tabular}{cccc}
\hline \multirow{2}{*}{ Catalysts } & \multicolumn{2}{c}{ Total Reducible Species } & Cerium Species \\
\cline { 2 - 4 } & $\begin{array}{c}\text { Temperature } \\
\left({ }^{\circ} \mathbf{C}\right)\end{array}$ & $\begin{array}{c}\mathbf{H}_{\mathbf{2}} \text { Consumption } \\
(\mathbf{m m o l} / \mathbf{g})\end{array}$ & $\begin{array}{c}\mathbf{H}_{\mathbf{2}} \text { Consumption } \\
(\mathbf{m m o l} / \mathbf{g})\end{array}$ \\
\hline $\mathrm{Au} / \mathrm{CeO}_{2}$ & $50-220$ & 0.30 & 0.30 \\
$\mathrm{Au} / \mathrm{Ce}_{0.95} \mathrm{Mn}_{0.05}$ & $50-210$ & 0.36 & 0.31 \\
$\mathrm{Au} / \mathrm{Ce}_{0.9} \mathrm{Mn}_{0.1}$ & $50-270$ & 0.52 & 0.33 \\
$\mathrm{Au} / \mathrm{Ce}_{0.8} \mathrm{Mn}_{0.2}$ & $50-340$ & 0.73 & 0.28 \\
$\mathrm{Au} / \mathrm{Ce}_{0.7} \mathrm{Mn}_{0.3}$ & $50-350$ & 1.02 & 0.26 \\
$\mathrm{Au} / \mathrm{Ce}_{0.6} \mathrm{Mn}_{0.4}$ & $50-350$ & 1.42 & 0.24 \\
$\mathrm{Au} / \mathrm{Mn}_{2} \mathrm{O}_{3}$ & $200-430$ & 5.50 & - \\
$\mathrm{Au} / \mathrm{Ce}_{0.9} \mathrm{Mn}_{0.1} 1_{2}$ & $50-270$ & 0.24 & 0.12 \\
$\mathrm{Au} / \mathrm{Ce}_{0.9} \mathrm{Mn}_{0.1}$ & $50-270$ & 0.23 & 0.12 \\
\hline
\end{tabular}

${ }^{1}$ Spent catalyst after $6 \mathrm{~h}^{2}$ spent catalyst after $44 \mathrm{~h}$.

\subsection{Catalytic Performance}

The dehydrogenation of ethane was conducted in the presence of $\mathrm{CO}_{2}$ over supported Au catalysts at $650{ }^{\circ} \mathrm{C}$, and the results are shown in Table 3 and Figure 5. Carbon balance was determined by the ratio of the overall hydrocarbon amounts after the reaction to the initial ethane amount. High carbon balance was obtained for all the catalysts investigated, indicating that the dry reforming can be ignored during the reaction. Coke formation always accompanied the dehydrogenation reaction, though the addition of $\mathrm{CO}_{2}$ was suggested to react with these carbon deposits through the Boudouard reaction. This is probably why the carbon balance here did not reach $100 \%$. Except for coke, all the catalysts exhibit excellent selectivity to the target product ethylene and the only detectable by-product is methane. Although the pure oxide-supported catalysts $\mathrm{Au} / \mathrm{CeO}_{2}$ and $\mathrm{Au} / \mathrm{Mn}_{2} \mathrm{O}_{3}$ showed comparable initial activity, the former exhibited much better stability during the reaction. The ethane conversion of the $\mathrm{Au} / \mathrm{CeO}_{2}$ was maintained with no distinct loss of activity within $6 \mathrm{~h}$ of reaction while that of $\mathrm{Au} / \mathrm{Mn}_{2} \mathrm{O}_{3}$ dropped sharply from $16.4 \%$ to $4.2 \%$, indicating the different active sites on the two catalysts. Apparently, the ceria-supported Au catalyst is much preferable in the DHE reaction. For Mn-doped $\mathrm{CeO}_{2}$-supported Au catalysts, the initial ethane conversion was enhanced with the doping of $\mathrm{Mn}$ until the $\mathrm{Mn} /(\mathrm{Ce}+\mathrm{Mn})$ ratio reached 0.1 , and then decreased slightly with the further increase of the ratio. $\mathrm{Au} / \mathrm{Ce}_{0.9} \mathrm{Mn}_{0.1}$ achieved the highest initial activity with an ethane conversion of $22.4 \%$ and ethylene yield of $22.2 \%$. The initial ethane conversion of $\mathrm{Au} / \mathrm{Ce}_{1-x} \mathrm{Mn}_{x} \mathrm{O}_{2-\delta}$ has exactly the same sequence as that of the consumed hydrogen attributing to 
the ceria species, indicating that the easily reducible oxygen species related to ceria may play a vital role in the dehydrogenation reaction. Turnover frequency (TOF) was also calculated and compared to that of $\mathrm{Ga}_{2} \mathrm{O}_{3} / \mathrm{ZSM}-5$ and $\mathrm{Cr}_{2} \mathrm{O}_{3} / \mathrm{ZSM}-5$ published before. It seems that $\mathrm{Au}$ species are more active than $\mathrm{CrO}_{x}$ or $\mathrm{GaO}_{x}$ species (Table 3).

Table 3. Reaction data in the DHE in the presence of carbon dioxide ${ }^{1}$.

\begin{tabular}{|c|c|c|c|c|c|c|}
\hline \multirow{2}{*}{ Catalysts } & \multirow{2}{*}{$\begin{array}{c}\text { Conversion } \\
\left(^{(\%)^{2}}\right.\end{array}$} & \multicolumn{2}{|c|}{ Selectivity $(\%)^{2}$} & \multirow{2}{*}{$\begin{array}{c}\mathrm{C}_{2} \mathrm{H}_{4} \text { Yield } \\
(\%)^{2}\end{array}$} & \multirow{2}{*}{$\begin{array}{l}\text { TOF }^{4} \\
\left(h^{-1}\right)\end{array}$} & \multirow{2}{*}{$\begin{array}{c}\text { Carbon } \\
\text { Balance }(\%\end{array}$} \\
\hline & & $\mathrm{CH}_{4}$ & $\mathrm{C}_{2} \mathrm{H}_{4}$ & & & \\
\hline Blank & $0.9(0.9)$ & $26.5(25.7)$ & $73.5(74.4)$ & $0.7(0.7)$ & - & 99.3 \\
\hline $\mathrm{Au} / \mathrm{CeO}_{2}[14]$ & $17.2(17.1)$ & $2.4(2.1)$ & $97.6(97.9)$ & $16.8(16.7)$ & 40.8 & 94.0 \\
\hline $\mathrm{Au} / \mathrm{Ce}_{0.95} \mathrm{Mn}_{0.05}$ & 20.4(19.9) & $2.0(1.8)$ & $98.0(98.2)$ & $20.0(19.5)$ & 48.4 & 93.0 \\
\hline $\mathrm{Au} / \mathrm{Ce}_{0.9} \mathrm{Mn}_{0.1}$ & $22.7(20.6)$ & $2.0(1.7)$ & $98.0(98.3)$ & $22.2(20.3)$ & 53.9 & 92.7 \\
\hline $\mathrm{Au} / \mathrm{Ce}_{0.8} \mathrm{Mn}_{0.2}$ & $22.4(19.6)$ & $2.3(1.9)$ & 97.7(98.1) & $21.9(19.2)$ & 53.2 & 95.7 \\
\hline $\mathrm{Au} / \mathrm{Ce}_{0.7} \mathrm{Mn}_{0.3}$ & $20.2(16.9)$ & 2.1(1.9) & $97.9(98.1)$ & $19.8(16.5)$ & 48.0 & 95.7 \\
\hline $\mathrm{Au} / \mathrm{Ce}_{0.6} \mathrm{Mn}_{0.4}$ & $17.3(14.4)$ & $2.2(2.2)$ & $97.8(97.8)$ & $16.9(14.1)$ & 41.1 & 95.5 \\
\hline $\mathrm{Au} / \mathrm{Mn}_{2} \mathrm{O}_{3}$ & $16.4(4.2)$ & $1.8(5.5)$ & 98.2(94.5) & $16.1(4.0)$ & 38.9 & 94.2 \\
\hline $\mathrm{Ce}_{0.9} \mathrm{Mn}_{0.1}$ & $10.2(8.8)$ & $3.8(3.3)$ & $96.2(96.7)$ & $9.8(8.5)$ & - & 93.0 \\
\hline $\mathrm{Au} / \mathrm{CeO}_{2}{ }^{3}[14]$ & $14.1(1.5)$ & $5.9(19.8)$ & $94.1(80.2)$ & $13.2(1.2)$ & 33.5 & 95.0 \\
\hline $\mathrm{Au} / \mathrm{Ce}_{0.9} \mathrm{Mn}_{0.1}{ }^{3}$ & 19.4(1.3) & $29.8(20.0)$ & $70.2(80.0)$ & $13.6(1.0)$ & 46.1 & 92.4 \\
\hline $\mathrm{Ga}_{2} \mathrm{O}_{3} / \mathrm{ZSM}-5$ [9] & $25.3(14.6)$ & $6.1(5.4)$ & $91.7(92.0)$ & $23.2(13.4)$ & 5.3 & - \\
\hline $\mathrm{Cr}_{2} \mathrm{O}_{3} / \mathrm{ZSM}-5$ [10] & $65.5(61.3)$ & $24.3(20.9)$ & 75.4(78.9) & $49.4(48.4)$ & 20.0 & - \\
\hline
\end{tabular}

${ }^{1}$ Reaction condition: $200 \mathrm{mg}$ catalyst, $650{ }^{\circ} \mathrm{C}, 3 \% \mathrm{C}_{2} \mathrm{H}_{6} / 15 \% \mathrm{CO}_{2}$ in $\mathrm{N}_{2}$, flow rate $30 \mathrm{~mL} / \mathrm{min} .{ }^{2}$ The values outside and inside the brackets are obtained at $10 \mathrm{~min}$ and $6 \mathrm{~h}$, respectively. ${ }^{3}$ Reaction condition: $200 \mathrm{mg}$ catalyst, $650{ }^{\circ} \mathrm{C}, 3 \%$ $\mathrm{C}_{2} \mathrm{H}_{6}$ in $\mathrm{N}_{2}$, flow rate $30 \mathrm{~mL} / \mathrm{min}$. ${ }^{4}$ Turnover frequency (TOF) was defined for the (reacted $\mathrm{C}_{2} \mathrm{H}_{6}$ molecules)/(Au, $\mathrm{Ga}$ or $\mathrm{Cr}$ atoms $\times$ time).
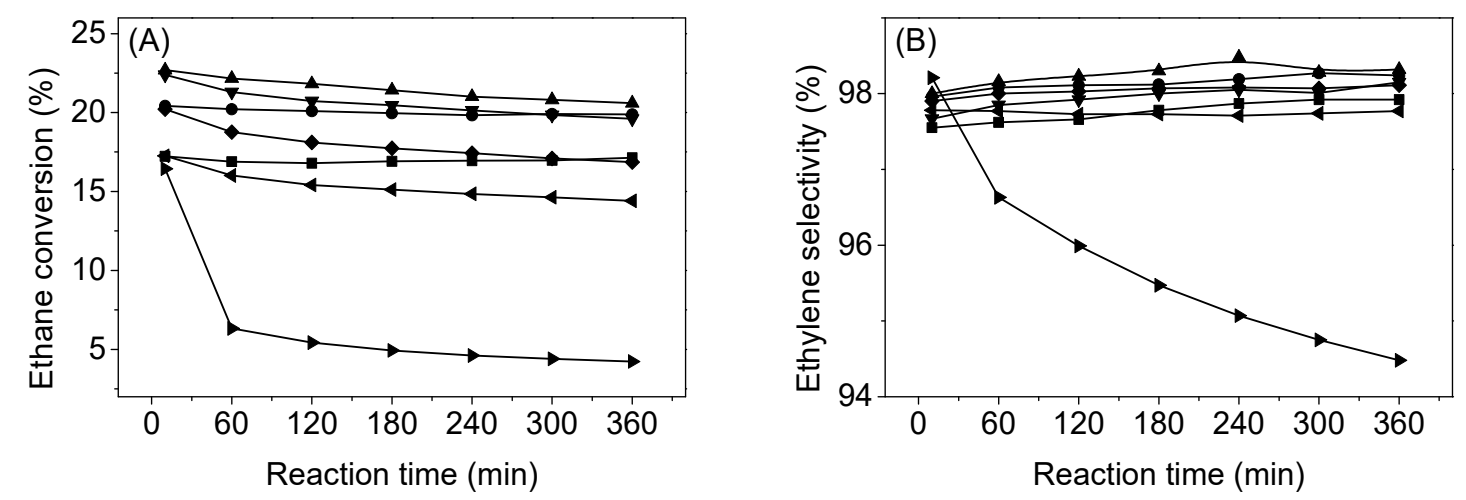

Figure 5. Ethane conversion (A) and ethylene selectivity $(\mathbf{B})$ over various Au catalysts in the presence of $\mathrm{CO}_{2}:(\boldsymbol{\square}) \mathrm{Au} / \mathrm{CeO}_{2} ;(\bullet) \mathrm{Au} / \mathrm{Ce}_{0.95} \mathrm{Mn}_{0.05} ;(\boldsymbol{\Delta}) \mathrm{Au} / \mathrm{Ce}_{0.9} \mathrm{Mn}_{0.1} ;(\boldsymbol{\nabla}) \mathrm{Au} / \mathrm{Ce}_{0.8} \mathrm{Mn}_{0.2} ;(\bullet) \mathrm{Au} / \mathrm{Ce}_{0.7} \mathrm{Mn}_{0.3}$; (४) $\mathrm{Au} / \mathrm{Ce}_{0.6} \mathrm{Mn}_{0.4} ;(\bullet) \mathrm{Au} / \mathrm{Mn}_{2} \mathrm{O}_{3}$.

The dehydrogenation of ethane was also conducted over the $\mathrm{Ce}_{0.9} \mathrm{Mn}_{0.1}$ oxide and the result is also listed in Table 3 for comparison. Though the composite oxide itself also showed some DHE activity with ethane conversion of $10.2 \%$, it is much lower compared to its gold-loaded counterpart $\left(\mathrm{Au} / \mathrm{Ce}_{0.9} \mathrm{Mn}_{0.1}\right)$, revealing the considerable role of Au species in the ethane dehydrogenation over Mn-doped $\mathrm{CeO}_{2}$ supported Au catalysts. TPR measurements show that the addition of gold can remarkably reduce the temperature of the ceria reduction peak, thus enhancing the reducibility of oxygen species on the catalyst surface [33].

The ethane dehydrogenation over $\mathrm{Au} / \mathrm{Ce}_{0.9} \mathrm{Mn}_{0.1}$ was also investigated in the absence of $\mathrm{CO}_{2}$ to look into the role of $\mathrm{CO}_{2}$, and the results are presented in Figure 6 and Table 3. Like $\mathrm{Au} / \mathrm{CeO}_{2}$, the initial activity of $\mathrm{Au} / \mathrm{Ce}_{0.9} \mathrm{Mn}_{0.1}$ was promoted slightly after the addition of $\mathrm{CO}_{2}$ while the stability was greatly improved. The ethane conversion was decreased sharply with reaction time in the absence of $\mathrm{CO}_{2}$ and the activity was completely lost within the initial $6 \mathrm{~h}$. However, in the presence of $\mathrm{CO}_{2}$, over $20 \%$ conversion can be maintained during the same period. The promotion effects of $\mathrm{CO}_{2}$ over 
Mn-doped $\mathrm{CeO}_{2}$ nanorod-supported $\mathrm{Au}$ is quite similar as that of unmodified $\mathrm{Au} / \mathrm{CeO}_{2}$ [14], which will be discussed in detail later.

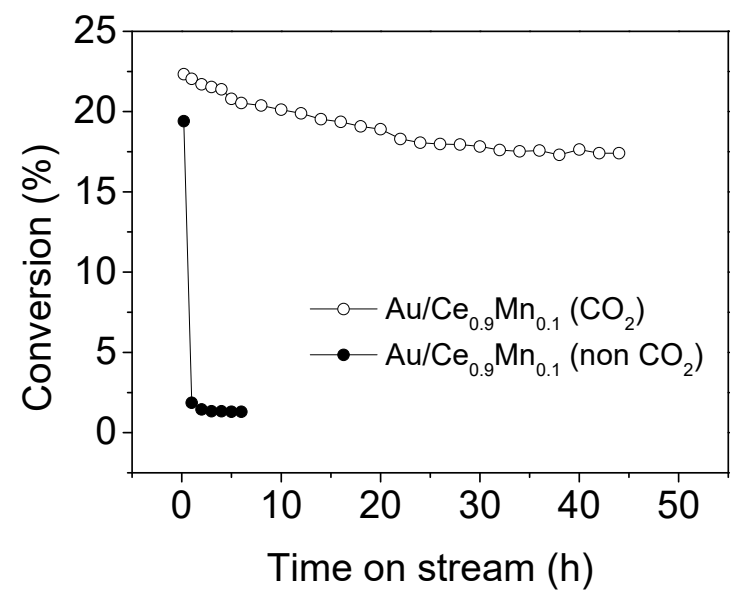

Figure 6. Ethane conversion of long-term dehydrogenation of $\mathrm{Au} / \mathrm{Ce}_{0.9} \mathrm{Mn}_{0.1}$ in the presence and absence of $\mathrm{CO}_{2}$.

In order to investigate the catalytic stability in more detail, a long-term test was conducted on the $\mathrm{Au} / \mathrm{Ce}_{0.9} \mathrm{Mn}_{0.1}$ catalyst and the results are illustrated in Figure 6 . The catalyst deactivated gradually with time on the stream, and finally reaches its steady state after about $30 \mathrm{~h}$. A steady ethane conversion of $17.4 \%$ with an ethylene selectivity of $97.5 \%$ can be obtained (i.e., TON $41.4,1 \mathrm{~h}$ ). It seems that the $\mathrm{Au} / \mathrm{Ce}_{0.9} \mathrm{Mn}_{0.1}$ can become a commercial dehydrogenation catalyst due to its high stability and excellent selectivity.

Coke deposition always acted as the major reason for catalyst deactivation. Raman analysis were performed to elucidate the nature and extent of carbonaceous deposits on the spent $\mathrm{Au} / \mathrm{Ce}_{0.9} \mathrm{Mn}_{0.1}$ catalyst. Peaks at $1324 \mathrm{~cm}^{-1}$ (D band) and $1576 \mathrm{~cm}^{-1}$ ( $\mathrm{G}$ band) were observed on the spent catalyst after dehydrogenation in the absence of $\mathrm{CO}_{2}$, which are assigned to disordered carbonaceous species and graphitic carbon, respectively. On the contrary, after dehydrogenation in the presence of $\mathrm{CO}_{2}$, the identical catalyst exhibited no distinct peaks in that range as shown in Figure S3. This implies that the addition of $\mathrm{CO}_{2}$ can suppress or eliminate the carbonaceous deposits effectively, which may account for the enhanced stability.

The redox property of spent $\mathrm{Au} / \mathrm{Ce}_{0.9} \mathrm{Mn}_{0.1}$ catalyst was investigated by $\mathrm{H}_{2}$-TPR, and the results are presented in Figure 7 and Table 2. For the catalyst after dehydrogenation in the presence of $\mathrm{CO}_{2}$, the TPR profiles are quite similar to that of the fresh one. The low-temperature reduction peak still remained without obvious shifts of peak temperature (still at $50 \sim 270{ }^{\circ} \mathrm{C}$ ), which indicates that their redox properties change little during the reaction. However, its peak intensity was reduced after reaction. The consumed hydrogen attributing to the ceria species decreased from $0.33 \mathrm{mmol} / \mathrm{g}$ to $0.12 \mathrm{mmol} / \mathrm{g}$ during the initial $6 \mathrm{~h}$, and was maintained at that level even after $44 \mathrm{~h}$ of reaction. Since the reducible oxygen species-related $\mathrm{CeO}_{2}$ were thought to play a crucial role in dehydrogenation, the decrease of these species may account for the partial deactivation of the catalyst. However, after dehydrogenation in the absence of $\mathrm{CO}_{2}$, the low-temperature peaks had completely disappeared. Some new peaks in the range of $200-400{ }^{\circ} \mathrm{C}$ emerged which were different from the inherent low-temperature reduction peaks of $\mathrm{CeO}_{2}$ oxides. These peaks can be attributed to the hydrogenation of deposited cokes according to the previous reports $[34,35]$. The loss of these reducible oxygen species is quite reasonable since the reaction was carried out under the reducing atmosphere at a relatively high temperature $\left(650{ }^{\circ} \mathrm{C}\right)$. It is evident that the addition of a mild oxidant $\mathrm{CO}_{2}$ can replenish the reducible oxygen species on the catalyst surface, thus stabilizing the activity during the dehydrogenation. 


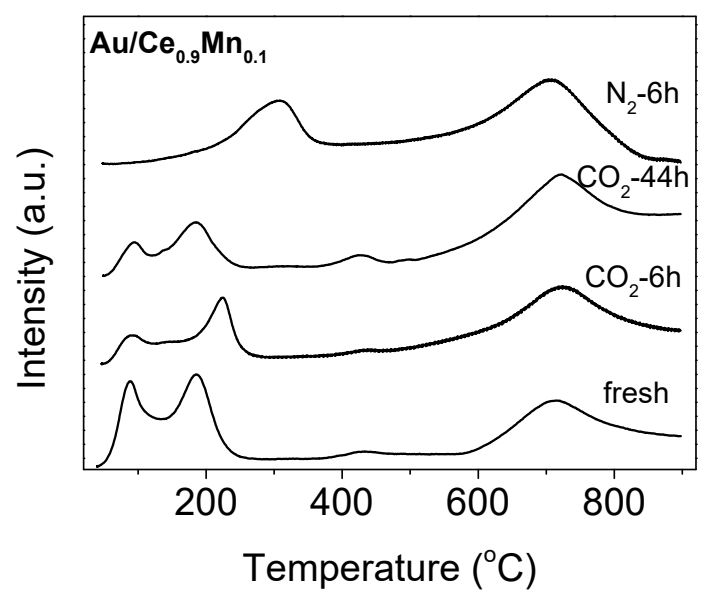

Figure 7. TPR profiles of fresh and spent $\mathrm{Au} / \mathrm{Ce}_{0.9} \mathrm{Mn}_{0.1}$ catalysts.

\section{Materials and Methods}

\subsection{Catalyst Preparation}

The Mn-doped $\mathrm{CeO}_{2}$ nanorod was synthesized by a modified hydrothermal method following the procedure in the literature [36]. Typically, the calculated amount of $\mathrm{Ce}\left(\mathrm{NO}_{3}\right)_{3} \cdot 6 \mathrm{H}_{2} \mathrm{O}$ and $50 \mathrm{wt} \%$ $\mathrm{Mn}\left(\mathrm{NO}_{3}\right)_{2}$ solution were dissolved in $20 \mathrm{~mL}$ deionized water; $38.4 \mathrm{~g} \mathrm{NaOH}$ was dissolved in another $140 \mathrm{~mL}$ of deionized water. The above two solutions were then mixed and kept stirring for $30 \mathrm{~min}$ to form a slurry. The slurry was transferred into a Teflon-lined stainless-steel autoclave and subjected to hydrothermal treatment for $24 \mathrm{~h}$ at $100{ }^{\circ} \mathrm{C}$. The obtained precipitates were recovered by filtration, washed thoroughly with deionized water, dried at $100{ }^{\circ} \mathrm{C}$ and finally calcined at $450{ }^{\circ} \mathrm{C}$ for $3 \mathrm{~h}$. These materials were denoted as $\mathrm{Ce}_{1-x} \mathrm{Mn}_{x} \mathrm{O}_{2-\delta}$ while $x$ represents the molar ratio of $\mathrm{Mn} /(\mathrm{Ce}+\mathrm{Mn})$.

Deposition of Au was prepared by a deposition-precipitation (DP) method. The $\mathrm{Ce}_{1-x} \mathrm{Mn}_{x} \mathrm{O}_{2-\delta}$ solid was dispersed in an aqueous solution of $\mathrm{HAuCl}_{4}$ at a fixed $\mathrm{pH}$ of 7.5. The Au loading was 1.0 $\mathrm{wt} \%$. The suspension was aged at room temperature for $24 \mathrm{~h}$ and then washed with deionized water. After being dried at $100{ }^{\circ} \mathrm{C}$, these Au-containing materials were calcined in air at $650{ }^{\circ} \mathrm{C}$ for $6 \mathrm{~h}$, and denoted as $\mathrm{Au} / \mathrm{Ce}_{1-x} \mathrm{Mn}_{x} \mathrm{O}_{2-\delta}$.

\subsection{Catalyst Characterizations}

X-ray powder diffraction (XRD) patterns were recorded on Persee XD-2 X-ray diffractometer (Persee, Beijing, China) using nickel-filtered $\mathrm{Cu} \mathrm{K} \alpha$ radiation at $40 \mathrm{kV}$ and $30 \mathrm{~mA}$. X-ray photoelectron spectra (XPS) were obtained by using Mg K $\alpha$ radiation on a Perkin-Elmer PHI 5000C spectrometer (Perkin-Elmer, Boston, MA, USA). The BET surface areas of the catalysts were analyzed by $\mathrm{N}_{2}$ adsorption at $-196^{\circ} \mathrm{C}$ using a Micromeritics ASAP 2000 instrument (Micromeritics, Atlanta, GA, USA). Transmission electron microscopy (TEM) images were recorded on a JEOL 2011 electron microscope (JEOL, Tokyo, Japan) operating at $200 \mathrm{kV}$. Temperature-programmed reduction $\left(\mathrm{H}_{2}-\mathrm{TPR}\right)$ was carried out on a Micromeritics AutoChem II apparatus (Micromeritics, Atlanta, GA, USA) loaded with $100 \mathrm{mg}$ of catalyst under a $10 \mathrm{vol} \% \mathrm{H}_{2} /$ Ar flowing gas $(30 \mathrm{~mL} / \mathrm{min})$, with a ramping rate of $10{ }^{\circ} \mathrm{C} / \mathrm{min}$. The consumption of $\mathrm{H}_{2}$ was monitored using a thermal conductivity detector. Laser Raman spectra were obtained on a Horiba JY XPloRA spectrometer (HORIBA, Tyoto, Japan) using the $532 \mathrm{~nm}$ radiation of an air-cooled solid state laser as an excitation source.

\subsection{Catalyst Evaluation}

Catalytic tests for ethane dehydrogenation were performed at $650{ }^{\circ} \mathrm{C}$ in a fixed-bed flow microreactor at atmospheric pressure. The catalyst load was $200 \mathrm{mg}$, and it was activated at $650{ }^{\circ} \mathrm{C}$ for $2 \mathrm{~h}$ in nitrogen flow prior to the reaction. Typically, the gas reactant contained $3 \mathrm{vol} \%$ ethane, 
$15 \mathrm{vol} \% \mathrm{CO}_{2}$ and the balance nitrogen. For reactions carried out in the absence of $\mathrm{CO}_{2}$, the gas reactant contained $3 \mathrm{vol} \%$ ethane and the balance nitrogen. The total flow rate of the gas reactant is $30 \mathrm{~mL} / \mathrm{min}$. The hydrocarbon reaction products were analyzed using an on-line GC equipped with a $6 \mathrm{~m}$ packed column of Porapak $\mathrm{Q}$ and a FID. The gas products, such as $\mathrm{N}_{2}, \mathrm{CO}$ and $\mathrm{CO}_{2}$, were analyzed on-line by another GC equipped with a $2 \mathrm{~m}$ packed column of carbon molecular sieve 601 and a TCD. The reaction data in the work were reproducible with a precision of less than $5 \%$.

\section{Conclusions}

The catalytic dehydrogenation of ethane to ethylene was conducted in the presence of $\mathrm{CO}_{2}$ over Mn-doped ceria nanorod-supported Au catalysts. The initial ethane conversion was enhanced with the Mn doping. XPS analysis showed the predominated $\mathrm{Mn}^{3+}$ fraction in the $\mathrm{Au} / \mathrm{Ce}_{1-x} \mathrm{Mn}_{x} \mathrm{O}_{2-\delta}$ catalysts and a monotonously decreased $\mathrm{Ce}^{3+}$ concentration with the doping of $\mathrm{Mn}$, suggesting that the doped Mn might preferentially occupy the defect sites of $\mathrm{CeO}_{2}$ crystals and cause the formation of extra oxide ions. The TPR measurement showed that the consumed hydrogen attributing to the ceria species of the $\mathrm{Au} / \mathrm{Ce}_{1-x} \mathrm{Mn}_{x} \mathrm{O}_{2-\delta}$ catalysts shared a similar sequence with the DHE performance, indicating that these reducible oxygen species-related ceria might play a vital role in the dehydrogenation.

The addition of $\mathrm{CO}_{2}$ slightly promoted the initial activity but greatly improved the stability of $\mathrm{Au} / \mathrm{Ce}_{0.9} \mathrm{Mn}_{0.1}$ by eliminating the carbonaceous deposits through the Boudouard reaction and sustainably supplementing the reducible oxygen specie on the surface. The long-time test showed that $\mathrm{Mn}$-doped $\mathrm{CeO}_{2}$ nanorod-supported $\mathrm{Au}$ is a promising catalyst for ethane dehydrogenation in the presence of $\mathrm{CO}_{2}$. A steady ethane conversion of $17.4 \%$ with an ethylene selectivity of $97.5 \%$ can be obtained.

Supplementary Materials: The following are available online at http://www.mdpi.com/2073-4344/9/2/119/s1, Figure S1: XPS spectra of the Au/Ce ${ }_{1-x} \mathrm{Mn}_{x} \mathrm{O}_{2-\delta}$ catalysts, Figure S2: Deconvolution of the TPR profiles of the $\mathrm{Au} / \mathrm{Ce}_{1-x} \mathrm{Mn}_{x} \mathrm{O}_{2-\delta}$ catalysts, Figure S3: Raman profiles of the spent $\mathrm{Au} / \mathrm{Ce}_{0.9} \mathrm{Mn}_{0.1}$ catalysts.

Author Contributions: Y.Y. conceived and designed the experiments; T.L. and H.G. performed the experiments; W.H., C.M. and Z.G. analyzed the data; T.L. wrote the paper; W.H., C.M. and Y.Y. revised the paper.

Funding: This research was funded by the National Key R\&D Program of Ministry of Science and Technology, grant number 2017YFB0602204, National Natural Science Foundation of China, grant number 91645201 and the Science \& Technology Commission of Shanghai Municipality (13DZ2275200).

Conflicts of Interest: The authors declare no conflict of interest.

\section{References}

1. Nawaz, Z. Light alkane dehydrogenation to light olefin technologies: A comprehensive review. Rev. Chem. Eng. 2015, 31, 413-436. [CrossRef]

2. Sattler, J.J.H.B.; Ruiz-Martinez, J.; Santillan-Jimenez, E.; Weckhuysen, B.M. Catalytic dehydrogenation of light alkanes on metals and metal oxides. Chem. Rev. 2014, 114, 10613-10653. [CrossRef] [PubMed]

3. Wang, S.B.; Zhu, Z.H. Catalytic conversion of alkanes to olefins by carbon dioxide oxidative dehydrogenation. Energy Fuel 2004, 18, 1126-1139. [CrossRef]

4. Ansari, M.B.; Park, S.E. Carbon dioxide utilization as a soft oxidant and promoter in catalysis. Energy Environ. Sci. 2012, 5, 9419-9437. [CrossRef]

5. Mukherjee, D.; Park, S.E.; Reddy, B.M. $\mathrm{CO}_{2}$ as a soft oxidant for oxidative dehydrogenation reaction: An eco benign process for industry. J. $\mathrm{CO}_{2}$ Util. 2016, 16, 301-312. [CrossRef]

6. Atanga, M.A.; Rezaei, F.; Jawad, A.; Fitch, M.; Rownaghi, A.A. Oxidative dehydrogenation of propane to propylene with carbon dioxide. Appl. Catal. B 2018, 220, 429-445. [CrossRef]

7. Nakagawa, K.; Okamura, M.; Ikenaga, N.; Suzuki, T.; Kobayashi, T. Dehydrogenation of ethane over gallium oxide in the presence of carbon dioxide. Chem. Commun. 1998, 1025-1026. [CrossRef]

8. Nakagawa, K.; Kajita, C.; Okumura, K.; Ikenaga, N.; Nishitani-Gamo, M.; Ando, T.; Kobayashi, T.; Suzuki, T. Role of carbon dioxide in the dehydrogenation of ethane over gallium-loaded catalysts. J. Catal. 2001, 203, 87-93. [CrossRef] 
9. Cheng, Y.H.; Lei, T.Q.; Miao, C.X.; Hua, W.M.; Yue, Y.H.; Gao, Z. $\mathrm{Ga}_{2} \mathrm{O}_{3} / \mathrm{NaZSM-5}$ for $\mathrm{C}_{2} \mathrm{H}_{6}$ dehydrogenation in the presence of $\mathrm{CO}_{2}$ : Conjugated effect of silanol. Microporous Mesoporous Mater. 2018, 268, $235-242$. [CrossRef]

10. Cheng, Y.H.; Miao, C.X.; Hua, W.M.; Yue, Y.H.; Gao, Z. Cr/ZSM-5 for ethane dehydrogenation: Enhanced catalytic activity through surface silanol. Appl. Catal. A 2017, 532, 111-119. [CrossRef]

11. Lei, T.Q.; Miao, C.X.; Hua, W.M.; Yue, Y.H.; Gao, Z. Silica-doped $\mathrm{TiO}_{2}$ as support of gallium oxide for dehydrogenation of ethane with $\mathrm{CO}_{2}$. Fuel Process. Technol. 2018, 177, 246-254. [CrossRef]

12. Tóth, A.; Halasi, G.; Solymosi, F. Reactions of ethane with $\mathrm{CO}_{2}$ over supported Au. J. Catal. 2015, 330, 1-5. [CrossRef]

13. Tóth, A.; Halasi, G.; Bánsagi, T.; Solymosi, F. Reactions of propane with $\mathrm{CO}_{2}$ over Au catalysts. J. Catal. 2016, 337, 57-64. [CrossRef]

14. Lei, T.Q.; Miao, C.X.; Hua, W.M.; Yue, Y.H.; Gao, Z. Oxidative dehydrogenation of ethane with $\mathrm{CO}_{2}$ over $\mathrm{Au} / \mathrm{CeO}_{2}$ Nanorod catalysts. Catal. Lett. 2018, 148, 1634-1642. [CrossRef]

15. Zhang, L.; Wu, Z.; Nelson, N.C.; Sadow, A.D.; Slowing, I.I.; Overbury, S.H. Role of $\mathrm{CO}_{2}$ as a soft oxidant for dehydrogenation of ethylbenzene to styrene over a high-surface-area ceria catalyst. ACS Catal. 2015, 5, 6426-6435. [CrossRef]

16. Yao, H.C.; Yao, Y.F.Y. Ceria in automotive exhaust catalysts: I. Oxygen storage. J. Catal. 1984, 86, $254-265$. [CrossRef]

17. Lu, J.L.; Gao, H.J.; Shaikhutdinov, S.; Freund, H.J. Gold supported on well-ordered ceria films: Nucleation, growth and morphologh in CO Oxidation reaction. Catal. Lett. 2007, 114, 8-16. [CrossRef]

18. Reina, T.R.; Ivanova, S.; Centeno, M.A.; Odriozola, J.A. The role of $\mathrm{Au}, \mathrm{Cu} \& \mathrm{CeO}_{2}$ and their interactions for an enhanced WGS performance. Appl. Catal. B 2016, 187, 98-107.

19. Zhen, J.; Wang, X.; Liu, D.; Song, S.; Wang, Z.; Wang, Y.; Li, J.; Wang, F.; Zhang, H. $\mathrm{Co}_{3} \mathrm{O}_{4} @ \mathrm{CeO}_{2} \mathrm{Core}_{\text {Shell }}$ Cubes: Designed synthesis and optimization of catalytic properties. Chem. Eur. J. 2014, 20, 4469-4473. [CrossRef] [PubMed]

20. Su, Y.; Wang, S.; Zhang, T.; Wang, S.; Zhu, B.; Cao, J.; Yuan, Z.; Zhang, S.; Huang, W.; Wu, S. Comparative study on catalytic performances for low-temperature $\mathrm{CO}$ oxidation of $\mathrm{Cu}-\mathrm{Ce}-\mathrm{O}$ and $\mathrm{Cu}-\mathrm{Co}-\mathrm{Ce}-\mathrm{O}$ catalysts. Catal. Lett. 2008, 124, 405-412. [CrossRef]

21. Qi, G.S.; Yang, R.T.; Chang, R. $\mathrm{MnOx}-\mathrm{CeO}_{2}$ mixed oxides prepared by co-precipitation for selective catalytic reduction of $\mathrm{NO}$ with $\mathrm{NH}_{3}$ at low temperatures. Appl. Catal. B 2004, 51, 93-106. [CrossRef]

22. Delimaris, D.; Loannides, T. VOC oxidation over $\mathrm{MnOx}-\mathrm{CeO}_{2}$ catalysts prepared by a combustion method. Appl. Catal. B 2008, 84, 303-312. [CrossRef]

23. Venkataswamy, P.; Jampaiah, D.; Mukherjee, D.; Aniz, C.U.; Reddy, B.M. Mn-doped ceria solid solutions for CO oxidation at lower temperatures. Catal. Lett. 2016, 146, 2105-2118. [CrossRef]

24. Chen, H.Y.; Sayai, A.; Adnot, A.; Larahi, F. Composition-activity effects of Mn-Ce-O composites on phenol catalytic wet oxidation. Appl. Catal. B 2001, 32, 195-204. [CrossRef]

25. Si, R.; Flytzani-Stephanopoulos, M. Shape and crystal-plane effects of nanoscale ceria on the activity of $\mathrm{Au}-\mathrm{CeO}_{2}$ catalysts for the water-gas shift reaction. Angew. Chem. Int. Ed. 2008, 47, 2884-2887. [CrossRef] [PubMed]

26. Huang, X.S.; Sun, H.; Wang, L.C.; Liu, Y.M.; Fan, K.N.; Cao, Y. Morphology effects of nanoscale ceria on the activity of $\mathrm{Au} / \mathrm{CeO}_{2}$ catalysts for low-temperature $\mathrm{CO}$ oxidation. Appl. Catal. B 2009, 90, 224-232. [CrossRef]

27. Hong, W.J.; Iwamoto, S.; Hosokawa, S.; Wada, K.; Kanai, H.; Inoue, M. Effects of Mn content on physical properties of $\mathrm{CeOx}-\mathrm{MnOy}$ support and $\mathrm{BaO}-\mathrm{CeOx}-\mathrm{MnOy}$ catalysts for direct $\mathrm{NO}$ decomposition. J. Catal. 2011, 277, 208-216. [CrossRef]

28. Liyanage, A.D.; Perera, S.D.; Tan, K.; Chabal, Y.; Balkus, K.J. Synthesis, characterization, and photocatalytic activity of Y-doped $\mathrm{CeO}_{2}$ nanorods. ACS Catal. 2014, 4, 577-584. [CrossRef]

29. Gao, T.; Norby, P.; Krumeich, F.; Okamoto, H.; Nesper, R.; Fjellvag, H. Synthesis and properties of layered-structured $\mathrm{Mn}_{5} \mathrm{O}_{8}$ nanorods. J. Phys. Chem. C 2010, 114, 922-928. [CrossRef]

30. Larachi, F.; Pierre, J.; Adnot, A.; Bernis, A. Ce $3 d$ XPS study of composite $\mathrm{Ce}_{x} \mathrm{Mn}_{1-x} \mathrm{O}_{2-y}$ wet oxidation catalysts. Appl. Surf. Sci. 2002, 195, 236-250. [CrossRef]

31. Park, E.D.; Lee, J.S. Effects of pretreatment conditions on CO oxidation over supported Au catalysts. J. Catal. 1999, 186, 1-11. [CrossRef] 
32. Tang, X.F.; Chen, J.L.; Li, Y.G.; Xu, Y.D.; Shen, W.J. Complete oxidation of formaldehyde over Ag $/ \mathrm{MnO}_{x}-\mathrm{CeO}_{2}$ catalysts. Chem. Eng. J. 2006, 118, 119-125. [CrossRef]

33. Venezia, A.M.; Pantaleo, G.; Longo, A.; Carlo, G.D.; Casaletto, M.P.; Liotta, F.L.; Deganello, G. Relationship between structure and CO oxidation activity of ceria-supported gold catalysts. J. Phys. Chem. B 2005, 109, 2821-2827. [CrossRef]

34. Zhang, S.H.; Muratsugu, S.; Ishiguro, N.; Tada, M. Ceria-doped Ni/SBA-16 catalysts for dry reforming of methane. ACS Catal. 2013, 3, 1855-1864. [CrossRef]

35. Lan, G.J.; Tang, H.D.; Zhou, Y.P.; Han, W.F.; Liu, H.Z.; Li, X.N.; Li, Y. Direct synthesis of ruthenium-containing ordered mesoporous carbon with tunable embedding degrees by using a boric acid-assisted approach. ChemCatChem 2014, 6, 353-360. [CrossRef]

36. Mai, H.X.; Sun, L.D.; Zhang, Y.W.; Si, R.; Feng, W.; Zhang, H.P.; Liu, H.C.; Yan, C.H. Shape-selective synthesis and oxygen storage behavior of ceria nanopolyhedra, nanorods, and nanocubes. J. Phys. Chem. B 2005, 109, 24380-24385. [CrossRef]

(C) 2019 by the authors. Licensee MDPI, Basel, Switzerland. This article is an open access article distributed under the terms and conditions of the Creative Commons Attribution (CC BY) license (http://creativecommons.org/licenses/by/4.0/). 